\title{
Chromosome 5
}

National Cancer Institute

\section{Source}

National Cancer Institute. Chromosome 5. NCI Thesaurus. Code C13221.

The designation for each member of the fifth largest human autosomal chromosome pair. Chromosome 5 spans about 181 million base pairs and represents almost $6 \%$ of the total DNA in normal diploid cells. 